\title{
INCOME MODELLING OF ENTERPRISES ON THE BASIC OF VECTOR PREDICTION
}

E.N. Gorbatenko, Vladimir branch of the Financial University under the Government of the Russian Federation, ENGorbatenko@fa.ru, N.N. Manuylov, Vladimir branch of the Financial University under the Government of the Russian Federation, NNManujlov@fa.ru, S.V. Nikiforova, Vladimir branch of the Financial University under the Government of the Russian Federation, SVNikiforova@fa.ru

This paper proposes a new approach to income modelling of enterprises, based on the vector prediction methods. Existing approaches to the income modelling are based on the use of traditional methods of economic dynamics prediction such as the average absolute increase and average growth rate. Quantitative inaccuracy and highly approximate nature of predictions are inherent for traditional methods. The authors propose the economicmathematical model for the enterprise income planning for a year ahead on a quarterly basis. For revenue prediction two methods of vector prediction are used (the method of orthogonal differences and multiplicative Holt - Winters' method). This model provides prediction for a few steps forward at the same time. Individually, each of these methods doesn't take into account the diversity of the process. Only in conjunction the methods allow to take into account the demolition of trends and seasonal nature of income, thus providing the necessary stability of the prediction. To summarize two predictions their linear combination is calculated, the choice of weighting coefficients being based on the accuracy of private predictions. The accuracy of the private prediction is defined as the average relative error of the forecast.

Keywords: planning; business income; prediction; method of orthogonal differences; Holt - Winters' method; generalized forecast.

Enterprise efficiency is unthinkable without good income planning. The importance of planning of the company's income is due to the fact that the plan: contains guidelines, under which the company will operate; serves as a means of control by which management can determine the effectiveness of actions and plan measures to improve the organization's activities in future, and others.

In today's competitive environment, it is necessary to develop and apply new methods and techniques of planning, which would be based on the use of econometric models, selection and modification of the most appropriate ones. It turned out fundamentally important to consider features of organizations enterprises production structure, such as territorial remoteness and isolation of structural units (branches, holding companies), the activity conditions for each of them.

Analysis of the currently used techniques of companies income planning shows that they do not fully meet the requirements of practice. They do not take into account different conditions of unit work. Mathematical models of economic dynamics are not used for the examined trends analysis and modelling of changing indicators of the performance. Modern econometric methods are not applied in the process of prediction to ensure the adequacy and accuracy required in the calculations. Typically, the company's income planning is created for one year ahead for a head unit on the whole on a quarterly basis, and each regional (territorially separated) structural unit separately on the basis of the analysis 
and identification of trends in the growth and decline of income. Traditionally, planning approach is based on revenue prediction by means of the methods of the average absolute increase or average growth rate with the use of statistical data for the preceding three years. These prediction methods are attractive because of its simplicity, but they give good results only if previously prevailing trend of increasing or decreasing incomes is saved. If the trend change is reversed, you cannot use the method of progress in indicators forecasting and planning for future performance. It is important to identify the signs of trend change as early as possible, as well as to take into account seasonal fluctuations of income and other factors. This confirms the need to improve methods of revenue planning, using the data for more than 3 years and modern methods of adaptive prediction.

For the construction of economic and mathematical model formulation of the problem it is necessary to consider the problem of the company's income planning for the year ahead on a quarterly basis due to the type of income. The task of income planning is stated as follows: it is necessary to calculate the revenue targets for the business units for a year ahead on a quarterly basis and for certain types of income, taking into account the factors affecting them.

To realize planning we must take into account the background of the process and carry out its prediction. In this case, the original data is a matrix of quarterly business income indicators for the previous 4 years in size $(16, m)$, where $m$ - number of income types. It is necessary to construct a matrix of income prediction by size $(4, m)$ for the next year (quarterly and due to the articles of income).

To solve this problem, we divide the original matrix $(16, m)$ to $m$ 16-dimensional vectors. These vectors form $m$ of time series and for each of them it is necessary to predict 4 steps forward.

For predicting methods we use the vector prediction [1, 2], i.e., methods to obtain the prediction together with a few steps forward. These methods include: a method of orthogonal differences and multiplicative Holt - Winters' method.

The accuracy of the Holt - Winters' model depends on three smoothing parameters $\alpha_{1}, \alpha_{2}, \alpha_{3}$. Winters offers to find the values of these parameters experimentally by asking the net values of these parameters. The standard deviation of error appears as a criterion of comparison. The authors propose a solution to the problem of optimizing the parameters.Winters offers to find the values of these parameters experimentally by asking the net values of these parameters. The standard deviation of error appears as a criterion of comparison. The authors propose a solution to the problem of optimizing the parameters.

Forecast due to Holt - Winters' model is as follows. Building a model for a sample of $N$ observations ( $N=m n$, where $n$ - number of periods, a $m$ - number of values in the same period) is carried out in two stages.

At the first stage linear model $Z=a_{0}+b_{0} t$ is formulated. Furthermore, seasonality factors are calculated for the next stage:

$$
F_{k}^{0}=\frac{\frac{Y_{k}}{Z+k}+\frac{Y_{k+4}}{Z_{k+4}}}{2}, \quad k=1,2,3,4,
$$

where $Y_{k}$ - actual time series levels, $Z_{k}$ - calculated values of time series obtained by the linear model. 
At the second stage for each period with the number $i=1,2, \ldots, n$ and smoothing parameters $\alpha_{1}, \alpha_{2}, \alpha_{3}$ are computed

1) variables model coefficients $\left\{A_{k}^{i}\right\},\left\{B_{k}^{i}\right\}$;

2) seasonal coefficients $\left\{F_{k}^{i}\right\}$ for the next period;

3) calculated values of $\left\{Y_{p}^{i}(k)\right\}$, generating by the found model coefficients and seasonal coefficient the previous step. So, to calculation $i=1,2, \ldots, n$ is held by the formulas:

$$
\begin{gathered}
A_{k}^{i}=\alpha_{1} y_{k} / F_{k}^{i-1}+\left(1-\alpha_{1}\right)\left(A_{k}^{i-1}+B_{k}^{i-1}\right), \\
A_{k}^{0}=a_{0} \\
B_{k}^{0}=b_{0} \\
B_{k}^{i}=\alpha_{3}\left(A_{k}^{i}-A_{k}^{i-1}\right)+\left(1-\alpha_{3}\right) B_{k}^{i-1} \\
F_{k}^{i}=\alpha_{2} y_{k} / A_{k}^{i}+\left(1-\alpha_{2}\right) F_{k}^{i-1} \\
Y_{p}^{i}(k)=\left(A_{k}^{i}+k B_{k}^{i}\right) F_{k}^{i-1}
\end{gathered}
$$

Values prediction for the next $(n+1)$-th period is held by the formulas:

$$
Y_{p}^{n+1}(k)=\left(A_{k}^{n}+k B_{k}^{n}\right) F_{k}^{n}, \quad k=1,2,3,4 .
$$

The accuracy of this model is estimated on average relative error

$$
\bar{E}=\frac{1}{N} \sum_{k=1}^{N} \frac{\left|Y_{k}-Y_{p}(k)\right|}{Y_{k}} .
$$

The task is to find the optimal values of the parameters $\alpha_{1}, \alpha_{2}, \alpha_{3}$, minimizes the average relative error (2) under constraints (1). You can solve this problem by the method of coordinate descent.

To do this sequentially minimizing of the cost function (2) for each parameter separately, subject to constraints is carried out (1). Calculation scheme is as follows:

1) arbitrary values of the parameters $\alpha_{1}, \alpha_{2}, \alpha_{3}$ in the interval from 0 to 1 are fixed;

2) the function (2) in the variable $\alpha_{1}$ is minimizing;

3) optimum value $\alpha_{1}^{*}$ is stored;

4) the function (2) in the variable $\alpha_{2}$ at $\alpha_{1}=\alpha_{1}^{*}$ is minimizing;

5) optimum value $\alpha_{2}^{*}$ is stored;

6) the function (2) in the variable $\alpha_{3}$ at $\alpha_{1}=\alpha_{1}^{*}, \alpha_{2}=\alpha_{2}^{*}$ is minimizing;

7) optimum value $\alpha_{3}^{*}$ is stored.

As in items 2), 4), 6) optimal control problems are obtained again, but simpler than the original problem, then each of the resulting problem is solved by calculation of (1) and function (2) on the steps to the corresponding parameter in the range from 0 to 1.

As a result $\alpha_{1}^{*}, \alpha_{2}^{*}, \alpha_{3}^{*}$ will be found minimizing the cost function (2) subject to the constraints (1).

Let's consider a generalization of the method of orthogonal differences [2] for seasonal processes for four periods. Suppose there are time series of quarterly values for four years (Tab. 1).

Superscript values of the $y_{i}^{j}$ means the number of years, and the bottom - the quarter. The first difference in the two orthogonal directions is calculated. The first direction - the first differences in columns (Tab. 2).

In table 2 the first line $\left\{v_{i}^{1}\right\}$ - the result of subtracting from the second row of the first original series; the second line $\left\{v_{i}^{2}\right\}$ - the result of subtracting from the third row of the second original series, ie, value $v_{i}^{j}$ are calculated according to the formula $v_{i}^{j}=y_{i}^{j+1}-y_{i}^{j}$. 
Table 1

Quarterly revenues of the enterprise for four years

\begin{tabular}{|l|l|l|l|l|}
\hline Year & Q1 & Q2 & Q3 & Q4 \\
\hline 1 & $y_{1}^{1}$ & $y_{2}^{1}$ & $y_{3}^{1}$ & $y_{4}^{1}$ \\
2 & $y_{1}^{2}$ & $y_{2}^{2}$ & $y_{3}^{2}$ & $y_{4}^{2}$ \\
3 & $y_{1}^{3}$ & $y_{2}^{3}$ & $y_{3}^{3}$ & $y_{4}^{3}$ \\
4 & $y_{1}^{4}$ & $y_{2}^{4}$ & $y_{3}^{4}$ & $y_{4}^{4}$ \\
\hline
\end{tabular}

Table 2

Changes of quarterly earnings data

\begin{tabular}{|l|l|l|l|}
\hline$v_{1}^{1}$ & $v_{2}^{1}$ & $v_{3}^{1}$ & $v_{4}^{1}$ \\
$v_{1}^{2}$ & $v_{2}^{2}$ & $v_{3}^{2}$ & $v_{4}^{2}$ \\
$v_{1}^{3}$ & $v_{2}^{3}$ & $v_{3}^{3}$ & $v_{4}^{3}$ \\
$v_{1}^{4}$ & $v_{2}^{4}$ & $v_{3}^{4}$ & $v_{4}^{4}$ \\
\hline
\end{tabular}

The second direction - the first row to the difference in the initial series obtained by subtracting values of the values of the first column from the second column, etc. (Tab. 3).

Table 3

Changes in quarterly revenue due to quarter

\begin{tabular}{|l|l|l|l|}
\hline$w_{1}^{1}$ & $w_{2}^{1}$ & $w_{3}^{1}$ & $w_{4}^{1}$ \\
$w_{1}^{2}$ & $w_{2}^{2}$ & $w_{3}^{2}$ & $w_{4}^{2}$ \\
$w_{1}^{3}$ & $w_{2}^{3}$ & $w_{3}^{3}$ & $w_{4}^{3}$ \\
$w_{1}^{4}$ & $w_{2}^{4}$ & $w_{3}^{4}$ & $w_{4}^{4}$ \\
\hline
\end{tabular}

Here

$$
w_{1}^{1}=y_{2}^{1}-y_{1}^{1}, \quad w_{2}^{1}=y_{2}^{2}-y_{1}^{2}, \quad w_{1}^{3}=y_{2}^{3}-y_{1}^{3}, \ldots
$$

By differences $v_{i}^{j}$ and $w_{i}^{j}$ we can predict quarterly value $y_{i}^{j}$ for the fifth year. To do this gains quarterly $P_{i}=\frac{v_{i}^{1}+v_{i}^{2}+v_{i}^{3}}{3}, i=1,2,3,4$ are predicted first. This yields the first forecast for the fifth year: $x_{i}^{5}=y_{i}^{4}+P_{i}$.

On the other hand, using the values calculated by formulas (3), you can get

$$
B_{j}=\frac{w_{j}^{1}+w_{j}^{2}+w_{j}^{3}+w_{j}^{4}}{4}, j=1,2,3,4
$$

The second forecast for the fifth year: $z_{1}^{5}=x_{1}^{5}, z_{2}^{5}=x_{2}^{5}+B_{1}, z_{3}^{5}=z_{2}^{5}+B_{2}, z_{4}^{5}=z_{3}^{5}+B_{3}$.

These predictions are different and therefore we use a linear combination, preference being given to changes of the index over the years, not quarterly, as index is seasonal: $y_{i}^{5}=0,6 x_{i}^{5}+0,4 z_{i}^{5}, i=1,2,3,4$. 
To assess the accuracy of the prediction indicator of the average relative error is used.

Prediction error for the $j$-quarter of third year is calculated as follows: $E_{j}(3)=\left(y_{j}^{2}+\right.$ $\left.v_{j}^{1}\right)-y_{j}^{3}$, and for the fourth year $E_{j}(4)=\left(y_{j}^{3}+v_{j}^{2}\right)-y_{j}^{4}$.

The average relative error of the forecast for the $j$-th column is given by:

$$
\bar{E}=\frac{\frac{1}{2}\left(\left|E_{j}(3)\right|+\left|E_{j}(4)\right|\right)}{y_{j}^{4}} .
$$

The generalized forecast $\widehat{y_{0}}$ is represented as a linear combination of two private forecasts (forecast by Holt-Winter's method and the method of orthogonal differences): $\widehat{y_{0}}=\sum_{j=1}^{m} p_{j} \widehat{y_{j}}(m-$ number of combined forecasts $)$, where the weights are calculated on the basis of the accuracy of private forecasts. Forecast accuracy is defined as the inverse of the average relative error of the forecast $\frac{1}{\bar{E}_{j}}$.

Thus, the authors propose a new approach to enterprise income planning, based on the integrated use of two methods of prediction. Application of the developed method improves the enterprise management efficiency.

\title{
References
}

1. Garmash A.N., Gasparian M.S., Gorbatenko E.N. [On the Application of Mathematical Methods in the Planning of the Organization's Revenue]. Ekonomika, statistika i informatika [Economics, Statistics and Informatics. Bulletin of the UMO], 2011, no. 3, pp. 113-117.

2. Gorbatenko E.N. [Planning Income Postal Enterprises]. Obozrenie prikladnoy i promyshlennoy matematiki [Review of Applied and Industrial Mathematics], 2009, vol. 16, issue 5, pp. 830-832.

\section{МОДЕЛИРОВАНИЕ ДОХОДОВ ПРЕДПРИЯТИЙ НА ОСНОВЕ МЕТОДОВ ВЕКТОРНОГО ПРОГНОЗИРОВАНИЯ}

\author{
Е.Н. Горбатенко, Н.Н. Мануйлов, С.В. Никифорова
}

В статье предложен новый подход к моделированию доходов предприятий, основанный на методах векторного прогнозирования. Существующие подходы к моделированию доходов базируются на использовании традиционных методов прогнозирования показателей экономической динамики, таких как средний абсолютный прирост 
и средний темп роста. Традиционным методам свойственна количественная неточность и сильно приближенный характер прогнозов. Авторами предложена экономикоматематическая модель задачи планирования доходов предприятий на год вперед поквартально. Для прогнозирования доходов использованы два метода векторного прогнозирования (метод ортогональных разностей и мультипликативный метод ХольтаУинтерса). Данная модель позволяет получить прогноз на несколько шагов вперед одновременно. В отдельности каждый из методов не учитывает многообразия рассматриваемого процесса. Только в совокупности методы позволяют учитывать и слом тенденции, и сезонный характер доходов, тем самым обеспечивая необходимую устойчивость и надежность прогноза. Для обобщения двух прогнозов находится их линейная комбинация, при этом выбор весовых коэффициентов осуществляется на основе точности частных прогнозов. Точность этих частных прогнозов определяется как величина, обратно пропорциональная средней относительной ошибке прогноза.

Ключевые слова: планирование, доходы предприятий, прогнозирование, метод ортогональных разностей, метод Хольта - Уинтерса, обобщенный прогноз.

\section{Литература}

1. Гармаш, А.Н. О применении математических методов при планировании доходов организации / А.Н. Гармаш, М.С. Гаспариан, Е.Н. Горбатенко // Экономика, статистика и информатика. Вестник УМО. - 2011. - № 3. - С. 113-117.

2. Горбатенко, Е.Н. Планирование доходов предприятий почтовой связи / Е.Н. Горбатенко // Обозрение прикладной и промышленной математики. - 2009. - Т. 16, вып. 5. C. $830-832$.

Елена Николаевна Горбатенко, кандидат экономических наук, доцент, кафедра «Математика и информатика», Владимирский филиал Финуниверситета (г. Владимир, Российская Федерация), ENGorbatenko@fa.ru.

Николай Николаевич Мануйлов, кандидат физико-математических наук, доцент, кафедра «Математика и информатика», Владимирский филиал Финуниверситета (г. Владимир, Российская Федерация), NNManujlov@fa.ru.

Светлана Владимировна Никифорова, кандидат экономических наук, доцент, кафедра «Математика и информатика», Владимирский филиал Финуниверситета (г. Владимир, Российская Федерация), SVNikiforova@fa.ru.

Поступила в редакцию 11 апреля 2015 г. 